\title{
Motor and cognitive outcomes of low birth weight neonates born in a limited resource country: a systematic review
}

\section{Authors' names and affiliations:}

Graciane Radaelli ${ }^{\mathrm{a}^{* 1}}$, Eduardo Leal-Conceição ${ }^{\mathrm{a} 2}$, Felipe K. Neto ${ }^{\mathrm{a} 3}$, Melissa R. G. Taurisano $^{\mathrm{a} 4}$, Fernanda Majolo ${ }^{\mathrm{a} 5}$, Fernanda T. K. Bruzzo ${ }^{\mathrm{a} 6}$, Booij Linda ${ }^{\mathrm{c} 7}$, Magda L. Nunes $^{\mathrm{a}, \mathrm{b} 8}$

${ }^{a}$ Brain Institute of Rio Grande do Sul (BraIns), Pontifical Catholic University of Rio Grande do Sul, Porto Alegre, RS, Brazil;

${ }^{b}$ Professor of Neurology, School of Medicine, Pontifical Catholic University of Rio Grande do Sul, Porto Alegre, RS, Brazil;

${ }^{\mathrm{c}}$ Concordia University (Montreal - Canadá)

*Corresponding Author: Dra. Magda L. Nunes, Brain Institute Av. Ipiranga 6690, building 63 \#103, 90610-000, Porto Alegre, RS, Brazi. E-mail addresses: nunes@ pucrs.br.

1. ORCID id: 0000-0002-1208-362X; CV: http://lattes.cnpq.br/2829820424825932; E-mail: graciane.radaelli@pucrs.br

2. ORCID id: 0000-0001-9789-698X; CV: http://lattes.cnpq.br/9279978831152698; E-mail: co.eduardoleal@gmail.com

3. ORCID id: 0000-0002-7409-763X; CV: http://lattes.cnpq.br/8874509308176842; E-mail: felipekalil@ yahoo.com.br

4. ORCID id: 0000-0002-6744-1500; CV: http://lattes.cnpq.br/2024133504597692; E-mail:

melissa.taurisano@acad.pucrs.br

5. ORCID idः 0000-0002-7955-078X; CV: http://lattes.cnpq.br/3363064142425982; E-mail:

fernanda.majolo@acad.pucrs.br

6. ORCID id: 0000-003-2903-3618; CV: http://lattes.cnpq.br/0580402686566985; E-mail: fernanda.bruzzo@acad.pucrs.br

7. ORCID id: 0000-0002-0863-8098; E-mail: linda.booij@concordia.ca

8. ORCID id: 0000-0002-3402-6810; CV: http://lattes.cnpq.br/0580402686566985; E-mail: nunes@pucrs.br

\section{Funding}

This research did not receive any other specific grant from funding agencies in the public, commercial, or not-for-profit sectors.

\section{Conflicts of interest}

The authors declare no conflicts of interest. 


\section{Abstract}

Objective: To examine the outcomes of motor and cognitive development among neonates born with low birth weight (LBW) or very low birth weight (VLBW).

Data sources: Systematic review carried out in PubMed, Cochrane Library and Web of Science using the search strategy using combinations of the following keywords and terms: preterm birth OR prematurity OR premature Infants OR premature children AND low birth weight children OR very low birth weight children AND neurodevelopment OR cognitive development OR Motor development OR follow up AND humans. Articles searched were published from inception until July, 2019, and involved children born and evaluated in Brazil. The bias risk analysis was adapted from the STROBE scale, used to evaluate the methodology of the included studies.

Data synthesis: The search identified 2,214 publications. After screening for titles and abstracts and removing duplicate entries, full texts of 38 articles were reviewed. After reading full texts, 24 articles met the inclusion criteria (articles in Portuguese and English), dated from 1998 to 2017). Endnote Version X9 software was used for data extraction. Two reviewers performed the literature search and study selection independently. Disagreements were solved by consensus or by a third reviewer.

Results: it was evidenced an inferior motor development of children with LBW when compared to the control population, the standardized mean difference of [-1.15 (95\% CI 1.56, -0.73), $\mathrm{I}^{2} 80 \%$ ], children with LBW have lower cognitive development according the standardized mean difference of $[-0,71$ (95\% CI $\left.-0.99,-0.44) \mathrm{I}^{2} 67 \%\right]$.

Conclusion: Our review reinforces that impaired motor and cognitive outcome is a significant long-term outcome associated with LBW. The risk of impairment in those domains increases with decreasing gestational age.

Keywords: Motor development; outcome; prematurity; preterm infants; systematic review. 


\section{Introduction}

Strong evidence shows that children born prematurely or small for gestational age have a greater predisposition to deficits and / or delayed neuropsychomotor development ${ }^{1}$ and deficit rates are inversely related to gestational age and birth weight. ${ }^{2}$

Prematurity is a growing health problem worldwide, especially in developing countries where access to obstetric service and neonatal support is not guaranteed to the entire population. ${ }^{3}$ Worldwide 965.000 deaths occur in the neonatal period and 125.000 deaths between 1-5 years of age due to prematurity, representing the leading cause of neonatal and infant death. ${ }^{4}$ The worldwide incidence of deliveries before 37 weeks of gestation is $11.1 \%$ with large geographical differences, ranging from $5 \%$ in developed countries to $18 \%$ in countries with less economic power. ${ }^{5}$ In South America, the mortality of children born with very low birth weight reaches $26 \%,{ }^{5}$ demonstrating their socioeconomic lability.

Intrauterine growth restriction (IUGR) is an abnormal fetal growth standard that happens in approximately ten percent of gestations and is related with neonatal morbidity and mortality ${ }^{6}$ IUGR is a condition in which the fetus does not reach the expected weight during pregnancy, is defined as a rate of fetal growth that is less than normal for the expected growth potential of a particular infant, because of genetic or environmental factors, ${ }^{7}$ it is a pathologic inhibition of intrauterine fetal growth and the failure of the fetus to achieve its growth potential ${ }^{8}$. In IUGR pregnancies, the fetus attempts to prevent damage by slowing its growth and shortening its gestation, causing prematurity. ${ }^{6}$

The terms IUGR and small for gestational age (SGA) have been used as equals in the literature, although there is a difference. IUGR reflects fetal suffering, though SGA only provides a measure of size and not a measure of antenatal growth quality. ${ }^{6}$ SGA is a term used to describe neonates whose birth weight is bellow than the usual amount for the number of weeks of pregnancy, they usually are below the 10th percentile for babies of the same gestational age, or 2 deviations below. ${ }^{7}$

Subjects born with IUGR experience several poorer developmental outcomes, involving cognitive, socioemotional and behavioral domains, compared with children born appropriate for gestational age. ${ }^{6}$ IUGR is one of the main causes of perinatal and neonatal morbidity and mortality and contributes to long-term chronic diseases. ${ }^{7-9}$ Neurodevelopmental impairment, immediate perinatal adverse events (prematurity, cerebral palsy, intrauterine fetal death, neonatal death) and also to adult pathologic conditions are leading consequences of the IUGR. ${ }^{8,10}$ These neonates have different types of short-term 
and long-term problems making them vulnerable, both need immediately and long-term follow-up, especially for delayed onset of neurological disorder so that a quick intervention can be initiated on neurological and physical aspect and proceed to better disclosure. 9

The exposure to undernourishment early in life appears to have detrimental effects on the developing brain. ${ }^{11-13}$ Experimental studies conducted on animal models of early malnutrition and epilepsy, showed that malnutrition per se has effects not only on hippocampal morphology such as decreased neuronal density in CA1 and CA3 subfields and decreased NDMA expression during adulthood ${ }^{11,12}$ but also leads to progressive learning and memory disability. ${ }^{1}$ However, the enriched environment led to a significant benefit in learning and retention of visual-spatial memory being able to reverse the cognitive impairment. $^{13}$

The average intelligence quotient (IQ) of a child with low birth weight (LBW) is lower than a child with adequate birth weight. ${ }^{14}$ In addition to the reduced IQ, there are also greater learning difficulties and a greater need for special education in small for gestational age (SGAs) and preterm infants than in the general population. ${ }^{15}$ Cognitive deficits, school difficulties, and behavioral problems are often reported by children born with LBW or extreme preterm infants. ${ }^{1}$ While deficits have been reported across many cognitive domains, attention deficit is an area of concern for parents and teachers of premature children. ${ }^{16}$ Research shows that children born prematurely are much more at risk for neurobehavioral deficits even though there are individual variations and varying profiles and severity of deficits. ${ }^{1}$

The data concerning the medium or long-term outcomes of preterm newborns in South American countries remain deficient, and specific follow-up programs are challenging to provide in public institutions. After discharge from a neonatal intensive care unit (NICU), most of these infants are followed at primary care facilities, leaving most of them without specific attention. ${ }^{17}$

Given the great impact of low birth weight and/or prematurity on aspects of children neurodevelopment, it is extremely necessary to carry out studies that investigate these phenomena in greater depth in more heterogeneous populations like the ones from limited resources countries. The aim of this study was to examine the cognitive and motor outcomes of children with LBW or very low birth weight (VLBW), from studies conducted with the Brazilian population. Our hypothesis is that being raised in a limited resource country might have additional negative effects in the outcomes studied. 


\section{Methods}

This systematic review followed the criteria of the Preferred Reporting Items for Systematic Reviews and Meta-Analyses Checklist (PRISMA). ${ }^{18}$ The protocol of this systematic review was registered in international prospective register of systematic reviews (PROSPERO) under number CRD42019112403.

\section{Eligibility criteria}

The criteria used for study inclusion were: original articles that established an association between gestational weight (GA), birth weight (BW), and neurodevelopment in Brazilian children; studies published from inception until July 2019, in Portuguese and English, and that used the cohort, case-control, longitudinal, cross-sectional, descriptive analytical, and retrospective methods. The dependent variables used in this review were the variables obtained as the result of tests (receptive language and/or expressive language). The independent variables were GA, BW, gender, age at time of evaluation, family income, and maternal level of education. For the purposes of the present study, prematurity was considered at three levels: borderline preterm (GA 35-36 weeks), moderately preterm (GA 31-34 weeks), and extremely preterm (GA $\leq 30$ weeks). Newborns with low BW were classified as LBW $(<2,500 \mathrm{~g}), \operatorname{VLBW}(<1,500 \mathrm{~g})$, and ELBW $(<1,000 \mathrm{~g})$.

\section{Research strategies}

A systematic review was carried out in the PubMed, LILACS and SciELO databases, using combinations of the following keywords and terms: preterm birth OR prematurity OR premature Infants OR premature children AND low birth weight children OR very low birth weight children AND neurodevelopment OR cognitive development OR Motor development OR follow up AND humans.

\section{Data Synthesis}

Endnote Version X9 software was used for data extraction. The databases were searched and duplicate entries were removed. Abstracts that did not provide sufficient information regarding the inclusion and exclusion criteria were selected for full-text evaluation. In the second phase, the same reviewers independently evaluated the full text of these articles and made their selection in accordance with the eligibility criteria. Two reviewers (M.R.T. and 
F.T.B.) performed the literature search and study selection independently. Disagreements were solved by consensus or by a third reviewer.

Risk of bias in individual studies

Two authors (M.R.T. and F.T.B.) were in charge of reviewing the methodological quality and the risks of bias according to the scale adapted from STROBE Statement ${ }^{19}$, considering only the studies that fit the inclusion criteria. A third author (G.R.) evaluated and defined any disagreements. The STROBE Statement scale aims to evaluate studies not related to randomized clinical trials; it comprises 22 applicable questions/items to assess the quality and biases of articles. These criteria assess the quality of data, internal validity (biases and confounding factors), external validity, and the ability of the study to detect a significant effect. To assess the risk of bias using the STROBE criteria, the articles of this systematic review were grouped into three different categories, each with a specific score: (a) first category: articles involving prevalence-type cross-sectional studies, with a maximum score of 12; (b) second category: articles with a cross-sectional and cohort methodological design, with a maximum score of 22; (c) third category: articles involving case-control studies, with intervention and maximum score of 22 . To guarantee the proportion of results between the categories, the score obtained from each article was divided by the maximum possible score for each of the three established categories.

\section{Statistical analysis}

We performed random effects calculation of weighted estimated average Odds Ratios (OR). Heterogeneity and publication bias were assessed with the $\mathrm{I}^{2}$ metric and funnel plots/Egger's test, respectively. For continuous outcomes, if the unit of measurement was consistent throughout trials, results were presented as weighted mean difference with $95 \%$ of confidence intervals (CIs). Calculations were performed using random effects method and the statistical method used was inverse variance. Statistical significance defined for the analyzes as $p<0.05$. Statistical heterogeneity of the treatment effects among studies was assessed using Cochran's Q test and the inconsistency $\mathrm{I}^{2}$ test. Statistical heterogeneity of the treatment effects among studies will be assessed using the Cochran's Q test and the inconsistency I-squared test, in which values above $25 \%$ and $50 \%$ are considered to be indicative of moderate and high heterogeneity, respectively. ${ }^{20}$

\section{Results}

Study selection 
The initial database search resulted in 2409 articles. After removing the duplicate files, 2279 articles were filtered according to our inclusion criteria, from that 2217 were excluded by analyzing the titles and abstracts, resulting in 62 articles for evaluation of the full text. From the articles remained, 25 articles were selected and included in this review. ${ }^{21-44}$ The flowchart is shown in Fig. 1.

\section{Study characteristics}

Included studies were published between the years 1998-2017. The average sample size in the aforementioned studies was 95.64 ( $\mathrm{SD}=48.95)$, ranging from 32-262 participants. Approximately 52,8\% (SD=7,8\%) of the included samples were females. The mean birth weight of the premature participants was $1.477 \mathrm{~kg}$, with standard deviation \pm 0.424 and range $1.058-2.346 \mathrm{~kg}$. The mean gestational age in the premature children was $32 \pm 4.2$ weeks (range: $23-33.2$ weeks). Motor and cognitive assessments were performed at $29.2 \pm 24.5$ (0-96) months of birth. The details of the individuals studies are shown in Table 1.

Overview of functional relations with cognitive development in preterm

Of the included studies, 12 (48\%) were cohort studies, (12) 48\% cross sectional studies and 1 (4\%) was a case-control study. Among cohort studies, 6 studies (50\%) had a control group and 6 studies (50\%) did not have a control group. In the cross-sectional studies, only 4 studies $(33.3 \%)$ used a control group and 8 studies $(66.7 \%)$ did not. The only case-control study that was included used a control group (100\%). Most studies (19/76\%) evaluated cognitive and motor outcomes, 4 studies (16\%) only verified motor outcomes and 2 studies (8\%) only cognitive outcomes.

The most commonly used instruments used were: Bayley Scales of Infant Development, present in 13 (54.1\%) studies; Home Observation for Measurement of the Environment and Denver Developmental Screening Test, both present in four studies (16.6\%). An overview of functional relations with cognitive development in preterm/ low birth weight /very low birth weight children about the studies were demonstrated in Table 2.

\section{Risk of bias assessment about studies shows}

The assessment of the methodological quality and risk of bias is shown in Table 3. Of the 25 articles evaluated, a mean score of $93.16( \pm 3.9)$ was obtained, with a maximum score 
of $100.0 \%$ and a minimum score of $86 \%$. Thirteen articles showed values below the mean score and, therefore, were considered as lower methodological quality.

\section{Assessment of the Motor development in children}

Regarding the evaluation of motor development, we included five studies that had a control group to compare the scores in relation to the sample of premature / low weight individuals. The studies were grouped according to the tests used and an average of the standardized difference was calculated is shown in Fig. 2. The randomized effect model indicated the standardized mean difference of [-1.15 (95\% CI -1.56, -0.73), $\left.\mathrm{I}^{2} 80 \%\right]$. Thus, it is evidenced an inferior motor development of children with LBW when compared to the control population. The results of motor development described by cross-sectional studies without a control group, were only described according to Table 2, as it was not possible to calculate the scores due to the high heterogeneity between the studies.

\section{Assessment of the cognitive development in children}

To compare the results on cognitive development between the sample and the control population, five studies were included, according to the randomized effect model indicated the standardized mean difference of $[-0,71$ (95\% CI $\left.-0.99,-0.44) \mathrm{I}^{2} 67 \%\right]$, is shown in Fig. 3. Thusly, the studies indicated that children with LBW have lower cognitive development than term children. The results of cognitive development described by cross-sectional studies without a control group, were only described according to Table 2, as it was not possible to calculate the scores due to the high heterogeneity between the studies.

\section{Discussion}

Our review reinforces that impaired motor and cognitive outcome is a significant long-term complication associated with low birth weight or malnutrition. The risk of impairment increases the lower the weight.

Sacchi et al. ${ }^{6}$ examined cognitive outcomes of preterm and term-born children who had intrauterine growth restriction (IUGR) and were small for gestational age (SGA) compared with children who were appropriate for gestational age (AGA) during the first 12 years of life. Their main findings were that growth vulnerabilities assessed antenatally (IUGR) and at the time of birth (SGA) were significantly associated with lower childhood cognitive outcomes in preterm and term-born children compared with children with 
AGA. These findings demonstrate the need for early interventions in these high risk groups as well as it reiterates the results of our study.

In a similar study, Kesavan et al. ${ }^{7}$ reinforces that IUGR infants suffer significant morbidity with immediate and long-term health consequences. These infants are at high risk throughout their life and should be carefully monitored at different stages to ensure timely interventions toward prevention and management of various disorders affecting most organ systems. Enhancing these data, Eickman et al. ${ }^{23}$ showed that LBW infants had poorer motor and cognitive development than $\mathrm{ABW}$ term infants, concluding that birth weight is considered a risk factor for outcome. These results enhance our analysis, where motor and cognitive delays were found in children with LBW.

In the same path, Courchia et al. ${ }^{46}$ reported cognitive outcomes of 632 preterm infants evaluated in a single center between 1980 and 2015. Significant cognitive impairment for all infants decreased by $9.4 \%$ ( $\square \square=\square 0.015$ ) across the study period. For larger infants (birthweight $\square \geq \square 750 \square \mathrm{g}$ ), significant impairment decreased by $14.6 \%$ ( $\mathrm{p} \square=\square 0.002$ ). In smaller infants (birthweight $\square<\square 750 \square \mathrm{g}$ ) no significant changes were observed in cognitive outcomes over the study period. This cohort showed significant improvement in long term outcomes of infants since 1980.

Reinforcing the previously cited findings, Albu et al. ${ }^{8}$ and Sharma et al. ${ }^{9}$, associated IUGR with increased fetal and neonatal mortality and morbidity, being linked to immediate perinatal adverse events (prematurity, cerebral palsy, intrauterine fetal death, neonatal death). A selected study in our meta-analysis, Fuentefria et al. ${ }^{28}$ evidenced that VLBW preterm infants at 8 and 18 months corrected age showed significant differences in the neurodevelopment and growth pattern when compared with their full-term peers.

By exploring differences in neonatal body composition in a multi-ethnic population, and with the hypothesis that neonates from low and middle income countries (LAMIC) tend to have lower birth weight, Sletner et $\mathrm{al}^{47}$ found out that anthropometric measurements, such as abdominal circumference and ponderal index, were smaller in neonates from LAMIC origin when compared to western european neonates.

In a recent analysis of a Brazilian cohort. ${ }^{43}$ a comparison between 83 infants with birth weight $\leq 1,500 \mathrm{~g}$, and 52 control infants was made. VLBW infants at 8 and 18 months corrected age showed significant differences in the neurodevelopment and growth pattern when compared with their full-term peers.

In 2013, a cross-sectional study included children aged 6-7 from a historical birth cohort with low birth weight $(<2,500 \mathrm{~g})$ infants evaluated cognitive and behavioral 
development of preterm and low birth weight newborns living in a disadvantageous socioeconomic environment at school age. ${ }^{41}$ The total intelligence quotient varied from 70 to 140 . The borderline intelligence quotient was observed in $9.3 \%$ of the children and the Child Behavior Checklist indicated a predominance of social competence problems $(27.8 \%$, CI 19.2 to 37.9) compared with behavioral problems (15.5\%, CI 8.9 to 24.2). Thus, their conclusion suggests that these infants are at risk for developing disturbances in early school age, such as mild cognitive deficits and behavioral disorders. This risk might increase under unfavorable socioeconomic conditions.

However, as limitations of our study, it is extremely important to point out that the majority of Brazilian follow-up studies are old and seem to demonstrate a lack of homogeneity. Although 24 Brazilian studies were selected, only five demonstrated homogeneity to perform meta-analysis. Yet, data when compared with the most recent world literature, mostly reiterate the relationship of prematurity with delayed neurological outcome, regardless of the scales used for analysis. ${ }^{48,49}$

With this review it was shown that impaired neurodevelopmental outcome is a significant long-term complication associated with low birth weight and malnutrition. Also, IUGR and SGA increases the risk of neurodevelopmental impairment. Thus, low birth weight represents risks to cognitive and motor development of children born, especially in the early years of life. From the perspective of public health, it is essential that pediatricians are aware of the neuropsychomotor development of these children for proper treatment and follow-up.

\section{Ethical Publication Statement}

We confirm that we have read the Journal position on issues involved in ethical publication and affirm that this report is consistent with those guidelines.

\section{Figure and tables captions:}

Fig. 1. Summary of evidence search and study selection.

Fig. 2. Forest plots showing motor development in children.

Fig. 3. Forest plots showing cognitive development in children.

Table 1. Characteristics of the studies included in this systematic review. 
Table 2. Overview of functional relations with cognitive development in preterm/ low birth weight /very low birth weight children.

Table 3. Risk of bias assessment adapted from STROBE. ${ }^{19}$

\section{References}

1. Araujo, LB, Quadros, DA, Murata, MPF, \& Israel, VL. Neuropsychomotor development assessment of children aged 0 to 5 in early childhood public education centers. Revista CEFAC, 2019. 21(3), e12918. .

2. Saigal S, Doyle L. An overview of mortality and sequelae of preterm birth from infancy to adulthood. The Lancet. 2008; 371: 261-69.

3. Medina-Alva P, Duque KR, Zea-Vera A, Bellomo S, Cárcamo C, Guillen-Pinto D, et al. Combined predictors of neurodevelopment in very low birth weight preterm infants. Early Human Development. 2019; 130, 109-15.

4. Harrison MS, Goldenberg RL. Global burden of prematurity, Semin. Fetal Neonatal Med. 2016; 21:74-79.

5. Fernández R, D'Apremont I, Domínguez A, Tapia JL, Red Neonatal Neocosur. Survival and morbidity of very low birth weight infant in a south American neonatal network. Arch. Argent. Pediatr. 2014; 112: 405-12.

6. Sacchi C, Marino C, Nosarti C, Vieno A, Visentin S, Simonelli A. Association of Intrauterine Growth Restriction and Small for Gestational Age Status With Childhood Cognitive Outcomes: A Systematic Review and Meta-analysis [published online ahead of print, 2020 May 26]. JAMA Pediatr. 2020;174(8):1-10.

7. Kesavan K, Devaskar SU. Intrauterine Growth Restriction: Postnatal Monitoring and Outcomes. Pediatr Clin North Am. 2019 Apr;66(2):403-423.

8. Albu AR, Anca AF, Horhoianu VV, Horhoianu IA. Predictive factors for intrauterine growth restriction. J Med Life. 2014 Jun 15;7(2):165-71.

9. Sharma D, Farahbakhsh N, Shastri S, Sharma P. Intrauterine growth restriction - part 2. J Matern Fetal Neonatal Med. 2016 Dec;29(24):4037-48.

10. Salam RA, Das JK, Bhutta ZA. Impact of intrauterine growth restriction on long-term health. Curr Opin Clin Nutr Metab Care. 2014 May;17(3):249-54. 
11. Alvarez PS, Simão F, Hemb M, Xavier LL, Nunes ML.Effects of undernourishment, recurrent seizures and enriched environment during early life in hippocampal morphology. Int J Dev Neurosci. 2014 Apr;33:81-7. doi: 10.1016/j.ijdevneu.2013.12.004.

12. Wearick-Silva LE, Sebben AD, Costa-Ferro ZSM, Marinowic DR, Nunes ML. Undernourishment and recurrent seizures early in life impair Long-Term Potentiation and alter NMDAR and AMPAR expression in rat hippocampus. Int J Dev Neurosci. 2019 Jun;75:13-18. doi: 10.1016/j.ijdevneu.2019.03.005.

13. Simão F, Porto JA, Nunes ML. Effects of enriched environment in spatial learning and memory of immature rats submitted to early undernourish and seizures. Int $\mathrm{J}$ Dev Neurosci. 2012 Aug;30(5):363-7. doi: 10.1016/j.ijdevneu.2012.04.002.

14. Breslau N, Chilcoat H, DelDotto J, Andreski P, Brown G. Low birth weight and neurocognitive status at six years of age. Biological Psychiatry. 1996; 40: 389-97.

15. Hille ETM, Ouden AL, Bauer, L, Oudenrijn, C van den Brand R, Verloove-Vanhorick SP. School performance at nine years of age in very premature and very low birth weight infants: Perinatal risk factors and predictors at five years of age. The Journal of Pediatrics. 1994; 125: 426-34.

16. Anderson PJ, De Luca CR, Hutchinson E, Spencer-Smith MM, Roberts G, Doyle LW, Victorian Infant Collaborative Study Group. Attention problems in a representative sample of extremely preterm/extremely low birth weight children. Dev Neuropsychol. $2011 ; 36: 57-73$.

17. Fan RG, Portuguez MW, Nunes ML. Cognition, behavior and social competence of preterm low birth weight children at school age. Clinics (Sao Paulo). 2013;68(7):915-21.

18. Moher D, Liberati A, Tetzlaff J, Altmane DG, Group PRISMA. Preferred reporting items for systematic reviews and meta-analyses: the PRISMA statement. Int J Surg. 2010; 8:336-41.

19. STROBE. Information on the STROBE Statement. Available from: www.strobestatement.org [cited March, 2020].

20. Higgins JP, Thompson SG, Deeks JJ, et al. Measuring inconsistency in metaanalyses. BMJ. 2003;327(7414):557-60.

21. Bühler KEB, Limongi SCO, Diniz EMDA. Language and cognition in very low birth weight preterm infants with PELCDO application. Arquivos de Neuro-psiquiatria. 2009; 67: 242-49. 
22. Carvalho AEV, Martinez FE, Linhares MBM. Maternal anxiety and depression and development of prematurely born infants in the first year of life. The Spanish journal of psychology. 2008; 11: 600-08.

23. Eickmann SH, Lira PICD, Lima MDC. Mental and motor development at 24 months of full-term low birthweight infants. Arquivos de Neuro-Psiquiatria. 2002; 60: 748-54.

24. Emond AM, Lira PI, Lima MC, Grantham $\square$ Mcgregor SM, Ashworth A. Development and behaviour of low $\square$ birthweight term infants at 8 years in northeast Brazil: a longitudinal study. Acta Paediatrica. 2006; 95:1249-57.

25. Espírito Santo JD, Portuguez MW, Nunes ML. Status cognitivo-comportamental de prematuros de baixo peso ao nascimento em idade pré-escolar que vivem em país em desenvolvimento. Jornal de Pediatria. 2009; 85: 35-41.

26. Fan RG, Portuguez MW, Nunes ML. Cognition, behavior and social competence of preterm low birth weight children at school age. Clinics. 2013; 68: 915-21.

27. Fernandes LV, Goulart AL, Santos AMND, Barros MCDM, Guerra CC, Kopelman BI. Neurodevelopmental assessment of very low birth weight preterm infants at corrected age of 18-24 months by Bayley III scales. Jornal de Pediatria. 2012; 88: 471-78.

28. Fuentefria RN, Silveira, RC, Procianoy, RS. Neurodevelopment and Growth of a Cohort of Very Low Birth Weight Preterm Infants Compared to Full-Term Infants in Brazil. American journal of perinatology. 2018; 35: 152-62

29. Grantham-McGregor SM, Lira PI, Ashworth A, Morris SS, Assunção AM. The development of low birth weight term infants and the effects of the environment in northeast Brazil. The Journal of Pediatrics. 1998; 132: 661-66.

30. Guerra CC, de Moraes Barros MC, Goulart AL, Fernandes LV, Kopelman BI, dos Santos AM. Premature infants with birth weights of 1500-1999 g exhibit considerable delays in several developmental areas. Acta Paediatrica. 2014; 103: e1-e6.

31. Guimarães CL, Reinaux CM, Botelho AC, Lima G, Cabral Filho JE. Motor development evaluated by Test of Infant Motor Performance: comparison between preterm and full-term infants. Brazilian Journal of Physical Therapy. 2011; 15: 357-63.

32. Lemos RA, Frônio JDS, Ribeiro LC, Demarchi RS, Silva JD, Neves LAT. Functional performance according to gestational age and birth weight of preschool children born premature or with low weight. J Hum Growth Dev. 2012; 22: 17-26.

33. Magalhães LC, Rezende FCAD, Magalhães CM, Albuquerque PDRD. Comparative analysis of motor coordination in term and pre-term birth children at seven years of age. Revista Brasileira de Saúde Materno Infantil. 2009; 9: 293-300. 
34. Manacero S, Nunes ML. Evaluation of motor performance of preterm newborns during the first months of life using the Alberta Infant Motor Scale (AIMS). Jornal de Pediatria; 2008; 84: 53-59.

35. Meio MD, Lopes CS, Morsch DS. Prognostic factors for cognitive development of very low birth weight premature children. Revista de Saúde Pública. 2003; 37: 311-18.

36. Meio MD, Lopes, CS, Morsch DS, Monteiro AP, Rocha SB, Borges RA, Reis AB. Preschool cognitive development of very low birth weight preterm children. Jornal de Pediatria. 2004; 80: 495-502.

37. Mello RR, Dutra MVP, Silva KS, Lopes JMA. The predictive value of neonatal neurological assessment and neonatal cranial ultrasonography with respect to the development of very low birth weight premature infants. Revista de Saúde Pública. 1998; 32: 420-29.

38. Mello RR, Meio MD, Morsch DS, Silva KS, Dutra MV, Monteiro AV, Lopes JM. Normal neonatal cerebral ultrasonography in preterm infants-Is it possible to calm down the parents? Jornal de Pediatria. 1999; 75: 45-9.

39. Mello RRD, Silva KSD, Rodrigues MCCD, Chalfun G, Ferreira RC, Delamônica JVR. Predictive factors for neuromotor abnormalities at the corrected age of 12 months in very low birth weight premature infants. Arquivos de Neuro-psiquiatria; 2009; 67: 23541.

40. Oliveira GE, Magalhães LC, Salmela LF. Relationship between very low birth weight, environmental factors, and motor and cognitive development of children of 5 and 6 years old. Brazilian Journal of Physical Therapy; 2011; 15: 138-45.

41. Procianoy RS, Koch MS, Silveira RC. Neurodevelopmental outcome of appropriate and small for gestational age very low birth weight infants. Journal of child neurology; 2009; 24: 788-94.

42. Reis ABR, Mello RRD, Morsch DS, Meio MDBB, Silva KSD. Mental performance of very low birth weight preterm infants: assessment of stability in the first two years of life and factors associated with mental performance. Rev Bras Epidemiol. 2012;15:1324.

43. Schirmer CR, Portuguez MW, Nunes ML. Clinical assessment of language development in children at age 3 years that were born preterm. Arquivos de Neuropsiquiatria. 2006; 64: 926-31. 
44. Silva CAD, Brusamarello S, Cardoso FGC, Adamczyk NF, Rosa Neto F. Development of low birth weight preterm infants during the first two years of life. Revista Paulista de Pediatria. 2011; 29: 328-35.

45. Saccani, R., Martins, A. G., \& de Oliveira, P. (). Desenvolvimento motor no primeiro ano de vida de crianças prematuras conforme o peso de nascimento. Scientia Medica, 2017; 27(3), 1.

46. Courchia B, Berkovits MD, Bauer CR. Cognitive impairment among extremely low birthweight preterm infants from 1980 to present day. J Perinatol. 2019; 39:1098-104.

47. Sletner L, Nakstad B, Yajnik CS, Mørkrid K, Vangen S, Vårdal MH, Holme IM, Birkeland KI, Jenum AK. Ethnic differences in neonatal body composition in a multiethnic population and the impact of parental factors: a population-based cohort study. PLoS One. 2013 Aug 29;8(8):e73058.

48. Bayley N. Bayley Scales of Infant Development. 2nd ed. San Antonio, TX: The Psychological Corp; 1993.

49. Alberta Infant Motor Scale (AIMS): A Clinical Refresher And Update On Evaluation Of Normative Data. 2015. 
Fig. 1. Summary of evidence search and study selection

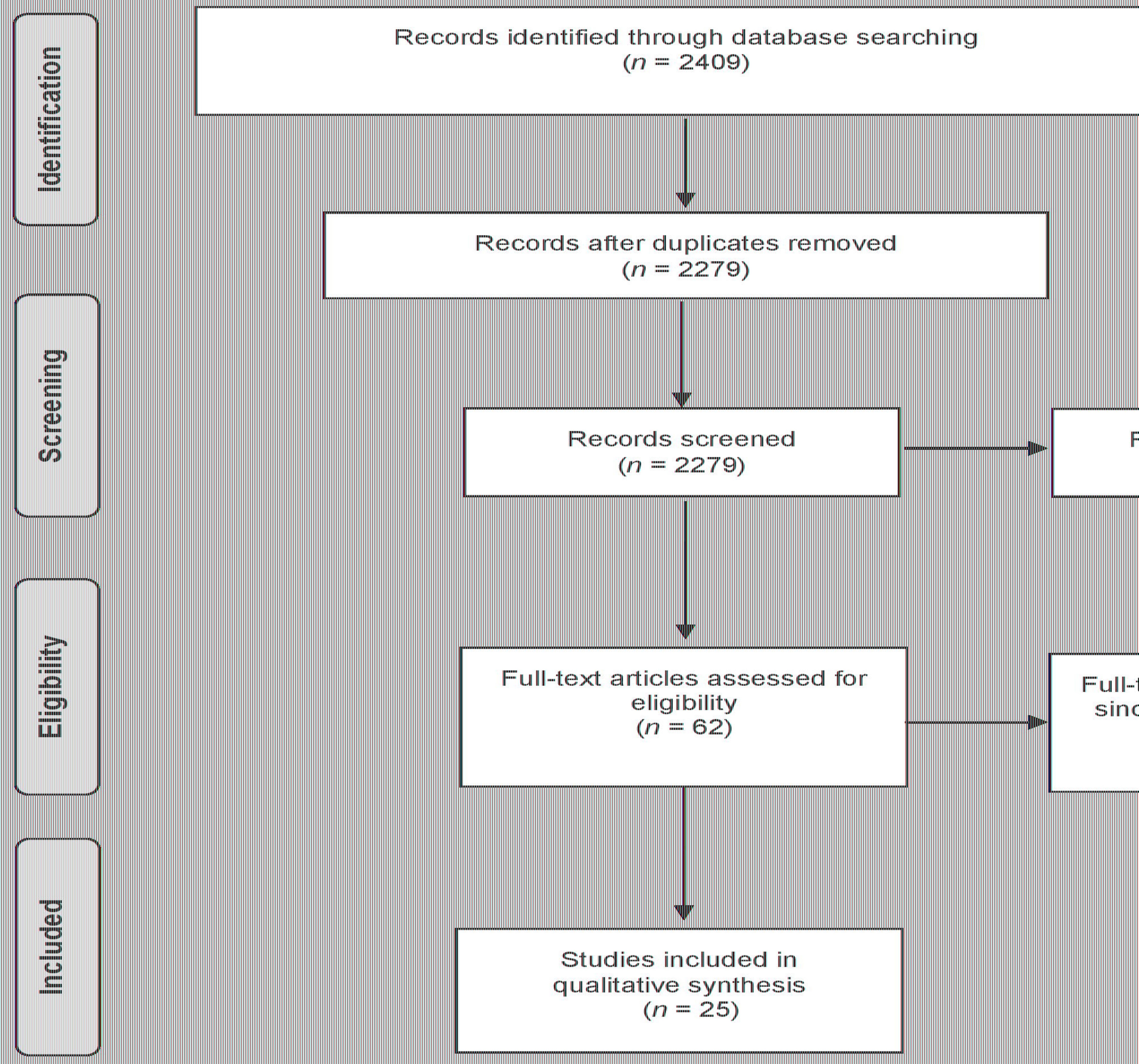




\section{Cognitive Development}

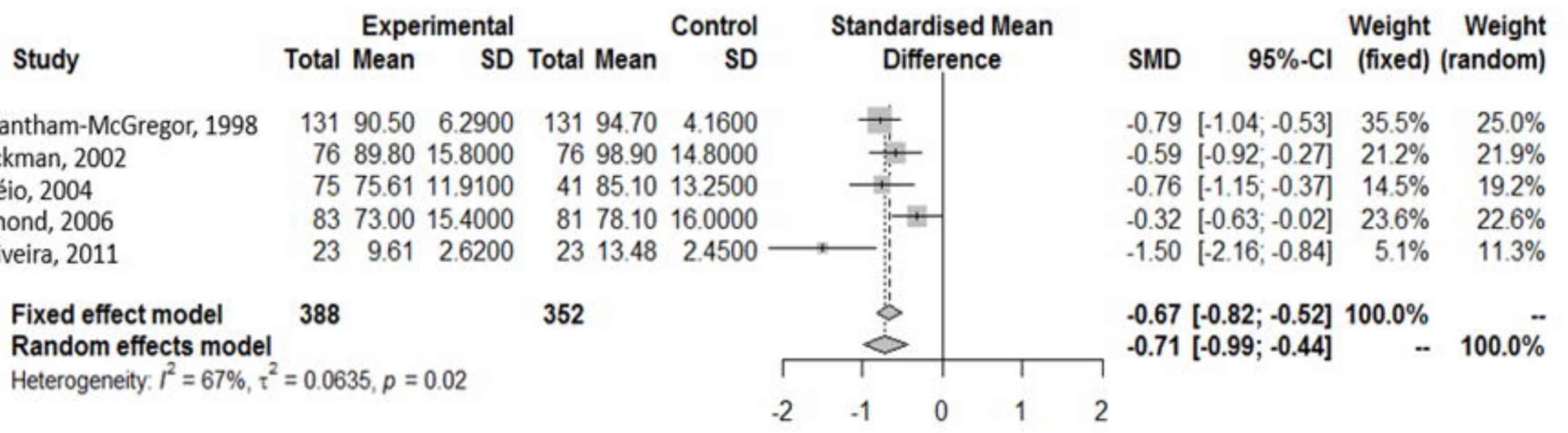


Table 1 Characteristics of the studies included in this systematic review.

\begin{tabular}{|c|c|c|c|c|c|c|}
\hline Author & Year & Birth weight & $\begin{array}{c}\text { Gestational age } \\
\text { in weeks }\end{array}$ & $\begin{array}{c}\text { Age of assessment } \\
\text { (months) }\end{array}$ & $\begin{array}{c}\text { Proportion } \\
\text { girls }\end{array}$ & $\mathbf{N}$ \\
\hline Mello et al. & 1998 & 1185 & 32.2 & 21 & 0.65 & 70 \\
\hline Grantham-McGregor et al. & 1998 & $2338 \times 3210$ & $37 \times 37$ & 6 to 12 & 0.615 & 262 \\
\hline Mello et al. & 1999 & 1176 & 32 & 12 to 30 & - & 83 \\
\hline Eickman et al. & 2002 & $3255 \times 2332$ & $>/=37$ & 24 & 0.58 & 152 \\
\hline Meio et al. & 2003 & 1903 & 32.04 & 48 to 60 & 0.64 & 79 \\
\hline Méio et al. & 2004 & 1220 & 32 & 0 to 36 & 0.62 & 129 \\
\hline Emond et al. & 2006 & $2346 \times 3212$ & $39 \times 40$ & 96 & - & 164 \\
\hline Schirmer et al. & 2006 & $1622 \times 1483$ & $33.18 \times 32.03$ & 36 & 0.53 & 69 \\
\hline Carvalho et al. & 2008 & 1058 & 30.44 & 12 & 0.5 & 36 \\
\hline Manacero et al. & 2008 & $1417 \times 2090$ & $32.4 \times 33.2$ & 4 to 8 & 0.34 & 88 \\
\hline Espirito Santo et al. & 2009 & 1788 & 32.3 & 48 to 60 & 0.5 & 80 \\
\hline Mello et al. & 2009 & 1126 & 29.6 & 12 & 0.53 & 100 \\
\hline Bühler et al. & 2009 & $3291 \times 1073$ & $39.1 \times 29.4$ & 24 & 0.43 & 32 \\
\hline Magalhães et al. & 2009 & $3215 \times 1171$ & $39.97 \times 30.23$ & 84 & 0.65 & 70 \\
\hline Procianoy et al. & 2009 & $1130 \times 1250$ & $31.7 \times 29.3$ & 24 & 0.49 & 131 \\
\hline Silva et al. & 2011 & 1236 & 31 & 24 & 0.42 & 69 \\
\hline Oliveira et al. & 2011 & $3273 \times 1201$ & $39 \times 30$ & 60 to 72 & 0.6 & 46 \\
\hline Guimarães et al. & 2011 & $3158 \times 1424$ & $38-40 \times 23-33$ & 36 & 0.5 & 92 \\
\hline Reis et al. & 2012 & 1122 & 29 & 24 & 0.53 & 109 \\
\hline Fernandes et al. & 2012 & 1172 & 30 & 18 to 2 & 0.51 & 58 \\
\hline Lemos et al. & 2012 & 1439 & 31 & 2 to 7 & 0.51 & 98 \\
\hline Fan et al. & 2013 & 1890 & 33,6 & 6 to 7 & 0.5 & 97 \\
\hline Guerra et al. & 2014 & $1727 \times 1762$ & $33.3 \times 33.2$ & 18 to 24 & 0.51 & 100 \\
\hline Fuentefria et al. & 2017 & $1098 \times 3348$ & $29.1 \times 39.1$ & 8 to 18 & 0.48 & 135 \\
\hline Saccani et al. & 2017 & $1886 \times 2878$ & $36 \times 36$ & 0 to 12 & - & 42 \\
\hline
\end{tabular}


Table 2 Overview of functional relations with cognitive development in preterm/ low birth weight /very low birth weight children.

\begin{tabular}{|c|c|c|c|c|c|c|c|}
\hline Study & Design & $\begin{array}{l}\text { Age } \\
N \\
\text { Sex }\end{array}$ & $B W(g), G A$ & Domains & Measures & Data analysis & Results \\
\hline Bühler et al. $^{21}$ & $\begin{array}{l}\text { Cohort } \\
\text { (incl control) }\end{array}$ & $\begin{array}{l}2 \text { years } \\
N=32 \\
\mathrm{n}_{1}=12 \mathrm{PT} \\
\mathrm{n}_{2}=20 \mathrm{FT} \\
\text { Sex unknown }\end{array}$ & $\begin{array}{l}\leq 1500 \\
\text { Mean BW: } 1073 \\
\text { GA: } 29.4 \\
\text { Vs } \\
\geq 2500 \\
\text { BW: } 3291 \\
\text { GA: } 39.1\end{array}$ & $\begin{array}{l}\text { Cognitive } \\
\text { expressive } \\
\text { Language } \\
\text { Motor }\end{array}$ & PELCDO & $\begin{array}{l}\text { Analysis of variance, (Mann- } \\
\text { Whitney test), Kruskal-Wallis } \\
\text { test Spearman correlations } \\
\text { tests }\end{array}$ & $\begin{array}{l}\text { VLBW preterm infants displayed poorer cognitive } \\
\text { development scores than term infants starting at } 6 \\
\text { months of age. Expressive language among VLBW } \\
\text { preterm infants was also delayed. }\end{array}$ \\
\hline$\underset{22}{\text { Carvalho et al. }}$ & $\begin{array}{l}\text { Cohort } \\
\text { (no control) }\end{array}$ & $\begin{array}{l}\mathrm{N}=36 \\
\text { Mothers and } \\
\text { their children }\end{array}$ & $\begin{array}{l}\mathrm{GA}<37 \\
\mathrm{BW}<2500\end{array}$ & $\begin{array}{l}\text { Motor and } \\
\text { cognitive } \\
\text { Enviroment }\end{array}$ & $\begin{array}{l}\text { Bayley-II Scale } \\
\text { STAI and BDI }\end{array}$ & $\begin{array}{l}\text { The data from the instruments } \\
\text { was analyzed according to their } \\
\text { respective standarts. STAl for } \\
\text { identification of mothers with } \\
\text { anxiety at an intermediary level. } \\
\text { BDI> } 20 \text { for depression. Data } \\
\text { were analyzed by the } \\
\text { Kolmogorov-Smirnov normality } \\
\text { test. Was used the McNemar } \\
\text { test for postpartum samples. }\end{array}$ & $\begin{array}{l}\text { The majority of the infants exhibited normal } \\
\text { development on Bayley-II at } 12 \text { months CCA; } \\
\text { however, } 25 \% \text { of the infants displayed cognitive } \\
\text { problems and } 40 \% \text { motor problems. The mothers' } \\
\text { anxiety and depression symptoms decreased at the } \\
\text { end of the first year of life of the pre-term infants } \\
\text { and the children showed predominately normal } \\
\text { development at this phase. }\end{array}$ \\
\hline Eickman et al. ${ }^{2 i 3}$ & $\begin{array}{l}\text { Cross-sectional } \\
\text { (incl control) }\end{array}$ & $\begin{array}{l}2 \text { years } \\
N=152 \\
64 \text { boys } \\
88 \text { girls } \\
n_{1}=76 \text { LBW } \\
n_{2}=76 \text { ABW }\end{array}$ & $\begin{array}{l}\text { 1500-2499 } \\
\text { BW: } 2332 \pm 160 \\
\text { Vs. } \\
\text { 3000-3499 } \\
\text { BW: } 2332 \pm 160\end{array}$ & $\begin{array}{l}\text { Motor and } \\
\text { cognitive } \\
\text { Environment }\end{array}$ & $\begin{array}{l}\text { Bayley Scale } \\
\text { HOME }\end{array}$ & $\begin{array}{l}\text { Chi-squared, Analysis of } \\
\text { variance (T-test), Multiple linear } \\
\text { regression. }\end{array}$ & $\begin{array}{l}\text { LBW term infants showed poorer motor } \\
\text { development }(95.1 \pm 19.2, p<.001) \text { than ABW term } \\
\text { infants }(105.3 \pm 13.6) \text { after controlling for SES } \\
\text { factors. Mental development followed the same } \\
\text { pattern }(89.8 \pm 15.8 \text { for LBW; } 98.9 \pm 14.8, p<.001) \text {. } \\
\text { BW was a risk factor for impaired motor and mental } \\
\text { development }(p=.010 ; p=.005) \text {. Socio-economic } \\
\text { level and home stimulation were predictors of both } \\
\text { motor and cognitive development }(p<.01) \text {. }\end{array}$ \\
\hline Emond et al. ${ }^{24}$ & $\begin{array}{l}\text { Cohort } \\
\text { (incl control) }\end{array}$ & $\begin{array}{l}8 \text { years } \\
\mathrm{N}=164 \\
\mathrm{n}_{1}=83 \mathrm{LBW}-\mathrm{T} \\
\mathrm{n}_{2}=81 \mathrm{ABW}-\mathrm{T} \\
\text { Sex unknown }\end{array}$ & $\begin{array}{l}1500-2499 \\
\text { BW: } 2346 \pm 148 \\
\text { GA: } 39 \pm 1.4 \\
\text { Vs. } \\
3000-3499 \\
\text { BW: } 3212 \pm 147 \\
\text { GA: } 40 \pm 1.3 \\
\text { All GA }>37\end{array}$ & $\begin{array}{l}\text { IQ } \\
\text { Memory } \\
\text { Attention } \\
\text { Motor and } \\
\text { cognitive } \\
\text { Coordination } \\
\text { Behaviour } \\
\\
\text { School } \\
\text { achievement } \\
\text { Environment }\end{array}$ & $\begin{array}{l}\text { WISC III } \\
\text { WISC } \\
\text { TEAch } \\
\text { Bayley Scale } \\
\text { M-ABC } \\
\text { Strengths and } \\
\text { Difficulties } \\
\text { questionnaires } \\
\text { Educational } \\
\text { assessments } \\
\text { HOME }\end{array}$ & $\begin{array}{l}\text { Comparison of means, Chi- } \\
\text { squared, Analysis of variance } \\
\text { (T-test, Mann-Whitney test), } \\
\text { Spearman correlations tests, } \\
\text { Multiple linear regression. }\end{array}$ & $\begin{array}{l}\text { LBW term infants were more vulnerable to have } \\
\text { motor and cognitive impairments. Home factors } \\
\text { (e.g. stimulation) as significant predictors on motor } \\
\text { and cognitive scores. Low developmental levels } \\
\text { among children with least-educated mothers. } \\
\text { Growth in head size was strongly associated with } \\
\text { IQ as a better predictor of cognitive outcomes than } \\
\text { BW. }\end{array}$ \\
\hline
\end{tabular}


Table 2 Continued (I)

\begin{tabular}{|c|c|c|c|c|c|c|c|}
\hline $\begin{array}{l}\text { Espirito Santo et } \\
\text { al. }^{25}\end{array}$ & $\begin{array}{l}\text { Cross-sectional } \\
\text { (no control) }\end{array}$ & $\begin{array}{l}4-5 \text { years } \\
N=80 \\
40 \text { boys } \\
40 \text { girls }\end{array}$ & $\begin{array}{l}\leq 2500+ \\
\text { Born preterm } \\
\text { Mean } \\
\text { BW: } 1788 \pm 502 \\
\text { GA: } 32.3 \pm 3 \\
\text { Subdivision } \\
<1000 \text { vs. }<1500 \\
\text { vs. } 1500-2500\end{array}$ & $\begin{array}{l}\text { IQ } \\
\text { Behaviour, ADHD } \\
\text { symptoms } \\
\text { Motor } \\
\text { Motor and } \\
\text { cognitive }\end{array}$ & $\begin{array}{l}\text { WPPSI, } \\
\text { CPRS-R } \\
\text { Denver Test } \\
\text { Bayley Scale } \\
\text { Neurological } \\
\text { examination }\end{array}$ & $\begin{array}{l}\text { Chi-square } \\
\text { Analysis of variance }\end{array}$ & $\begin{array}{l}\text { Significant positive correlations between Bayley } \\
\text { cognitive scale }(p<.05) \text { the Denver test }(p<.01) \text {, and } \\
\text { ADHD symptoms. Lower IQ was associated with } \\
\text { the Bayley cognitive scale }(p<.001) \text { the Denver test } \\
(p<.001) \text {, and neurobiological examination }(p<.01) \text {. }\end{array}$ \\
\hline Fan et al. ${ }^{26}$ & $\begin{array}{l}\text { Cross-sectional } \\
\text { (no control) }\end{array}$ & $\begin{array}{l}6-7 \text { years } \\
\mathrm{N}=97 \\
49 \text { girls } \\
48 \text { boys }\end{array}$ & $\begin{array}{l}\mathrm{GA}<37 \\
\mathrm{BW}<1500\end{array}$ & $\begin{array}{l}\text { Cognition } \\
\text { Motor and } \\
\text { cognitive } \\
\text { Motor and } \\
\text { cognitive } \\
\text { Behavior Social }\end{array}$ & $\begin{array}{l}\text { WISC-III } \\
\text { Bayley-II Scale } \\
\text { Denver-II Test } \\
\text { CBCL }\end{array}$ & $\begin{array}{l}\text { Z-test to compare the mean } \\
\text { values obtained in the sample } \\
\text { with the WISC-III reference. } \\
\text { Binomial confidence intervals } \\
\text { were used to describe the } \\
\text { percentages of the clinical } \\
\text { categories for the CBCL. The } \\
\text { data were analyzed using SPSS } \\
\text { v. } 15.0 \text {. }\end{array}$ & $\begin{array}{l}\text { The results of the Denver and Bayley tests were } \\
\text { associated with the cognitive performance ( } p, 0.001) \\
\text { and the Child Behavior Checklist social profile, } \\
\text { including aggressive and externalizing behavior } \\
(p, 0.001) \text {. }\end{array}$ \\
\hline $\begin{array}{l}\text { Fernandes et al. } \\
27\end{array}$ & $\begin{array}{l}\text { Cross-sectional } \\
\text { (no control) }\end{array}$ & $\begin{array}{l}18-24 \text { months } \\
N=58 \\
30 \text { girls } \\
28 \text { boys }\end{array}$ & $\begin{array}{l}\text { GA }<37 \\
\text { VLBW } \\
(<1500)\end{array}$ & $\begin{array}{l}\text { Motor and } \\
\text { cognitive }\end{array}$ & Bayley-III Scale & $\begin{array}{l}\text { Numerical variables were } \\
\text { compared by Mann-Whitney or } \\
\text { Student t test and categorical } \\
\text { variables by chi-square or } \\
\text { Fisher's exact test. Factors } \\
\text { associated with developmental } \\
\text { scores were analyzed by linear } \\
\text { regression, and statistical } \\
\text { significance level was } \\
\text { established at } p<0.05 \text {. }\end{array}$ & $\begin{array}{l}\text { Out of the } 58 \text { children included, four presented } \\
\text { cognitive delay, four motor, } 17 \text { language, } 16 \text { social- } \\
\text { emotional and } 22 \text { adaptive-behavior delay. The } \\
\text { female sex was associated with higher motor, } \\
\text { language and social-emotional developmental } \\
\text { scores }\end{array}$ \\
\hline
\end{tabular}


Table 2 Continued (II)

\begin{tabular}{|c|c|c|c|c|c|c|c|}
\hline $\begin{array}{l}\text { Fuentefria et al. } \\
28\end{array}$ & $\begin{array}{l}\text { Cohort } \\
\text { (incl control) }\end{array}$ & $\begin{array}{l}\mathrm{N}=135 \\
\text { Preterm } \\
\text { infants }(\mathrm{N}=83) \\
\text { Control group } \\
(\mathrm{N}=52)\end{array}$ & $\begin{array}{l}\text { Preterm } \\
\text { infants } \\
\text { GA: } 29.1 \\
\text { BW:1098 } \\
\text { Control group } \\
\text { GA: } 39.1 \\
\text { BW: } 3348\end{array}$ & $\begin{array}{l}\text { Motor } \\
\text { development } \\
\text { Psychomotor } \\
\text { development } \\
\text { Nutritional State }\end{array}$ & $\begin{array}{l}\text { AIMS } \\
\text { BLS }\end{array}$ & $\begin{array}{l}\text { SPSS, version } 21.0 \text {. To compare } \\
\text { the means between the groups, } \\
\text { the Student's t-test was applied. } \\
\text { For the control of confounding } \\
\text { factors, the analysis of } \\
\text { covariance (logistic regression) } \\
\text { was utilized. In the comparison } \\
\text { of proportions, Pearson's chi- } \\
\text { square test was used. The } \\
\text { associations between numerical } \\
\text { variables in each group were } \\
\text { evaluated by Pearson's } \\
\text { correlation coefficient. }\end{array}$ & $\begin{array}{l}\text { At } 8 \text { months corrected age, preterm infants scored } \\
\text { significantly lower in total AIMS score ( } p 1 / 40.001) \text {. } \\
\text { At } 18 \text { months, they scored significantly lower on the } \\
\text { stand subscale from AIMS ( } p 1 / 40.040 \text { ) and } \\
\text { exhibited poor psychomotor development in the } \\
\text { BLS ( } p 1 / 40.006) \text {. The nutritional status showed } \\
\text { significant differences between the groups, in both } \\
\text { age groups }(p<0.001) \text {. There were positive } \\
\text { correlations between nutritional status and AIMS ( } r \\
1 / 40.420 ; p<0.001 \text { ) and BLS }(r 1 / 40.456 ; p< \\
0.001) \text { at } 8 \text { months, and between head } \\
\text { circumference and BLS }(r 1 / 40.235 ; p<0.05) \text { at } 8 \\
\text { months and AIMS ( } r 1 / 40.258 ; p<0.05) \text { at } 18 \\
\text { months.Conclusion Very low BW preterm infants at } \\
8 \text { and } 18 \text { months corrected age showed significant } \\
\text { differences in the neurodevelopment and growth } \\
\text { pattern when compared with their full-term peers. }\end{array}$ \\
\hline $\begin{array}{l}\text { Grantham- } \\
\text { McGregor et al. }\end{array}$ & $\begin{array}{l}\text { Cohort } \\
\text { (incl control) }\end{array}$ & $\begin{array}{l}6 \text { and } 12 \text { months } \\
N=262 \\
n_{1}=131 \mathrm{LBW} \\
\mathrm{n}_{2}=131 \mathrm{ABW} \\
\text { Sex unknown }\end{array}$ & $\begin{array}{l}<2500 \\
\text { Mean BW: } \\
2338 \pm 152 \\
\text { vs. } \\
\geq 2500 \\
\text { Mean } \\
\text { BW: } 3210 \pm 142\end{array}$ & $\begin{array}{l}\text { Motor and } \\
\text { cognitive } \\
\text { Environment }\end{array}$ & $\begin{array}{l}\text { Bayley Scale } \\
\text { HOME }\end{array}$ & $\begin{array}{l}\text { Chi-squared, } \quad \text { Analysis of } \\
\text { variance (T-test), Multiple linear } \\
\text { regression }\end{array}$ & $\begin{array}{l}\text { LBW term infants showed poorer motor and } \\
\text { cognitive development than term infants. LBW term } \\
\text { infants with literate mothers had higher scores than } \\
\text { those with illiterate mothers ( } p=.003) \text {. Home factors } \\
\text { as significant predictors on motor and cognitive } \\
\text { scores. }\end{array}$ \\
\hline Guerra et al. ${ }^{30}$ & $\begin{array}{l}\text { Cross-sectional } \\
\text { (no control) }\end{array}$ & $\begin{array}{l}\mathrm{N}=100 \\
\text { With delay } \\
(\mathrm{N}=55) \\
\text { Without delay } \\
(\mathrm{N}=45)\end{array}$ & $\begin{array}{l}\text { With delay } \\
\text { GA: } 33.2 \\
\text { BW: } 1727 \\
\text { Without delay } \\
\text { GA: } 33.3 \\
\text { BW: } 1762\end{array}$ & $\begin{array}{l}\text { Motor and } \\
\text { cognitive }\end{array}$ & Bayley-III Scale & $\begin{array}{l}\text { The numerical variables were } \\
\text { compared by the Mann- } \\
\text { Whitney-U test or t-test and } \\
\text { the categorical variables by the } \\
\text { chi-square or Fisher's exact-test. }\end{array}$ & $\begin{array}{l}\text { The percentages and } 95 \% \text { confidence intervals of } \\
\text { those children with developmental delays were as } \\
\text { follows: cognitive }(2.0 \% ; 0.6-7.0 \%) \text {, language } \\
(5.0 \% ; 2.2-11.2 \%) \text {, motor }(3.0 \% \text {; } 1.0-8.5 \%) \text {, socio- } \\
\text { emotional }(13.0 \% ; 7.8-20.1 \%) \text {, general adaptive } \\
(26.0 \% ; 18.4-35.4 \%) \text {, conceptual }(17.0 \% ; 10.9- \\
25.6 \%) \text {, social }(46.0 \% ; 36.6-55.7 \%) \text { and practical } \\
(21.0 \% \text {; } 14.2-30.0 \%) \text {. Factors associated with } \\
\text { delay in at least one developmental domain were } \\
\text { as follows: caesarean delivery, low per capita } \\
\text { income and peri-intraventricular haemorrhage. } \\
\text { Factors associated with a reduction in } \\
\text { developmental scores were as follows: non-white } \\
\text { ethnicity, lower social class, caesarean delivery, } \\
\text { male gender, peri-intraventricular haemorrhage, } \\
\text { mechanical ventilation and length of hospitalisation. }\end{array}$ \\
\hline
\end{tabular}


Table 2 Continued (III)

\begin{tabular}{|c|c|c|c|c|c|c|c|}
\hline $\begin{array}{l}\text { Guimaraes et } \\
\text { al. }^{31}\end{array}$ & $\begin{array}{l}\text { Cross-sectional } \\
\text { (incl control) }\end{array}$ & $\begin{array}{l}3 \text { years } \\
\mathrm{N}=92 \\
\mathrm{n}_{1}=46 \mathrm{PT} \\
\mathrm{n}_{2}=46 \mathrm{FT} \\
\text { Sex: Unknown }\end{array}$ & $\begin{array}{l}\text { PT } \\
\text { GA:28-33 } \\
31.1 \pm 1.5 \\
\text { BW: } 1424 \pm 321.1 \\
\text { Vs. } \\
\text { FT } \\
\text { GA: } 38-40 \\
38.6 \pm 0.5 \\
\text { BW: } 3158 \pm 565.4\end{array}$ & Motor & TIMP & $\begin{array}{l}\text { Homogeneity of variance } \\
\text { between groups, Analysis of } \\
\text { variance (T-test, Mann-Whitney), } \\
\text { Spearman and Pearson } \\
\text { correlations, F-test. }\end{array}$ & $\begin{array}{l}\text { PT infants showed poorer motor development } \\
(58 \pm 7.9 ; p<.001) \text { than FT infants }(67.9 \pm 5.3) \text { after } \\
\text { controlling for SES factors. 100\% of PT were } \\
\text { showed atypical motor development ( } p<.001) \\
\text { whereas } 100 \% \text { of FT infants showed normal } \\
\text { scores. Prematurity was associated with impaired } \\
\text { motor development. }\end{array}$ \\
\hline Lemos et al. $^{32}$ & $\begin{array}{l}\text { Cross-sectional } \\
\text { (no control) }\end{array}$ & $\begin{array}{l}\text { Preschool } \\
\text { 7years) } \\
\mathrm{N}=98\end{array}$ & $\begin{array}{l}\mathrm{GA}<37 \\
\mathrm{BW}<2500\end{array}$ & $\begin{array}{l}\text { Self-care } \\
\text { Mobility Social } \\
\text { function }\end{array}$ & PEDI & $\begin{array}{l}\text { Chi-square and the variance } \\
\text { analysis. }\end{array}$ & $\begin{array}{l}\text { There was found a delay of } 10,2 \%, 12,2 \% \text { and } \\
14,3 \% \text { in the functional abilities in the areas of self- } \\
\text { care, mobility and social function, respectively, and } \\
\text { of } 11,2 \%, 19,4 \% \text { and } 15,3 \% \text { in the assistance level } \\
\text { received from the caregivers (independence), in the } \\
\text { same areas. It was not found statistically significant } \\
\text { differences or associations between groups of } \\
\text { different degrees of prematurity or birth weight and } \\
\text { the PEDI performance. }\end{array}$ \\
\hline $\begin{array}{l}\text { Magalhães et } \\
\text { al. }{ }^{33}\end{array}$ & $\begin{array}{l}\text { Cross-sectional } \\
\text { (incl control) }\end{array}$ & 7 years & $\begin{array}{l}\text { 1. } G A</=34 \\
B W</=1500 \\
\text { 2. } G A>37\end{array}$ & Motor & M-ABC test & Wilcoxon's test & $\begin{array}{l}\text { Significant difference between the two groups in } \\
\text { terms of the overall score }(Z=-4,866, p<0,001) \text { and } \\
\text { the score for specific sub-sections of the } M-A B C \text {, } \\
\text { the pre-term group performing less well than the } \\
\text { term group }\end{array}$ \\
\hline \multirow[t]{3}{*}{$\begin{array}{l}\text { Manacero and } \\
\text { Nunes }\end{array}$} & \multirow[t]{3}{*}{$\begin{array}{l}\text { Cross-sectional } \\
\text { (no control) }\end{array}$} & $\begin{array}{l}<1 \text { year } \\
\mathrm{N}=44\end{array}$ & $\leq 2500$ & \multirow[t]{2}{*}{ Motor } & AIMS & \multirow[t]{3}{*}{ Analysis of variance (ANOVA) } & \multirow{3}{*}{$\begin{array}{l}\text { Despite BW differences, motor ability acquisition } \\
\text { exhibited a normal progress at } 40 \text { weeks, } 4 \text { months, } \\
\text { and } 8 \text { months according to mean percentile of } \\
\text { normality on the AIMS ( } 43.2 \% \text { to } 45.7 \%)\end{array}$} \\
\hline & & $\begin{array}{l}21 \text { boys } \\
23 \text { girls } \\
n_{1}=14<1750\end{array}$ & $\begin{array}{l}\text { Subdivision } \\
<1750 \\
\text { BW: } 1417 \pm 292\end{array}$ & & $\begin{array}{l}\text { Neurological } \\
\text { examination }\end{array}$ & & \\
\hline & & $\mathrm{n}_{2}=30 \geq 1750$ & $\begin{array}{l}\text { GA:32.4 } \pm 0.7 \\
\text { vs. } \\
\geq 1750 \\
\text { BW: } 2090 \pm 278 \\
\text { GA:33.2 } \pm 0.8\end{array}$ & Motor & Denver Test & & \\
\hline Meio et al. ${ }^{35}$ & $\begin{array}{l}\text { Cohort } \\
\text { (no control) }\end{array}$ & $\begin{array}{l}N=94 \\
(64,6 \% \text { girls })\end{array}$ & $\begin{array}{l}\mathrm{GA}<37 \\
\mathrm{BW}<1500\end{array}$ & Cognitive & WPPSI-R & $\begin{array}{l}\text { T-student } \\
\text { Chi-squared with Yates } \\
\text { correction }\end{array}$ & $\begin{array}{l}\text { Seventy-nine children aged } 4 \text { and } 5 \text { years were } \\
\text { studied. The mean full WIPPSI-R score was } 75.6 \\
( \pm 11.9) \text {. The incidence of abnormal } 1 \text { and } 2 \mathrm{SD} \text { full } \\
\text { score was } 77.2 \% \text { and } 32.9 \% \text {, respectively. After } \\
\text { adjusting for the method of delivery, small for } \\
\text { gestational age (OR=6.19, } 95 \% \mathrm{Cl} 1.60-23.86) \text {, } \\
\text { abnormal cerebral ultrasound exam (OR }=5.90 \text {, } \\
95 \% \mathrm{Cl} \text { 1.04-9.83) and male sex (OR=3.20, } 95 \% \mathrm{Cl} \\
1.32-26.35) \text { were predictors of full score }<70 \text {. }\end{array}$ \\
\hline Meio et al. ${ }^{36}$ & $\begin{array}{l}\text { Cohort } \\
\text { (no control) }\end{array}$ & $\begin{array}{l}\mathrm{N}=79 / 129 \\
\text { Age pre-school }\end{array}$ & $\begin{array}{l}\mathrm{GA}<37 \\
\mathrm{BW}<1500\end{array}$ & Cognitive & WPPSI-R & $\begin{array}{l}\text { Epi-Info } 6.0 \\
\text { SPSS } 6.1 \\
\text { Chi-square } \\
\text { T-student } \\
\text { Fischer's test }\end{array}$ & $\begin{array}{l}\text { No significant statistical difference was found } \\
\text { between the groups (study and loss). Children who } \\
\text { entered this study showed to have a borderline } \\
\text { intellectual functioning at the moment of the } \\
\text { evaluation. Results indicate they may face learning } \\
\text { difficulties at school, thus requiring adequate stimuli } \\
\text { that should be provided by the family and the }\end{array}$ \\
\hline
\end{tabular}


school.

Table 2 Continued (IV)

\begin{tabular}{|c|c|c|c|c|c|c|c|}
\hline Mello et al. ${ }^{37}$ & $\begin{array}{l}\text { Cohort } \\
\text { control) }\end{array}$ & $\begin{array}{l}\mathrm{N}=70 \\
\text { Mean } \\
\text { GA:32.2 weeks }\end{array}$ & $\mathrm{GA}<37 \mathrm{BW}<1500$ & $\begin{array}{l}\text { Motor and } \\
\text { cognitive }\end{array}$ & $\begin{array}{l}\text { Dubowitz } \quad \& \\
\text { Dubowitz } \\
\text { method } \\
\text { brain US }\end{array}$ & $\begin{array}{l}\text { Analysis of variance through the } \\
\text { F-test; the differences between } \\
\text { the proportions were tested by } \\
\text { chi-square. The statistical } \\
\text { significance, prevalence, } \\
\text { sensitivity, specificities, } \\
\text { predictive values and confidence } \\
\text { intervals were calculated. }\end{array}$ & $\begin{array}{l}25.7 \% \text { of the children had neuromotor impairment, } \\
\text { and } 20.3 \% \text { had cognitive impairment. Neonatal } \\
\text { neurological examination was more sensitive than } \\
\text { neuromotor change (sensitivity: } 77.7 \% \text {, specificity: } \\
57.6 \%) \text {, and cognitive (sensitivity: } 78.5 \% \text {, } \\
\text { specificity: } 56.4 \%) \text {. Low predictive value for } \\
\text { neuromotor change (38.9\%) and cognitive ( } 31.4 \%) \text {. } \\
\text { Ultrasonography was discharged specificity for } \\
\text { neuromotor ( } 92.3 \% \text { ) and cognitive development } \\
(89.1 \%) \text {. The predictive value of ultrasonography } \\
\text { was high for neuromotor abnormalities }(69.2 \%) \text { and } \\
\text { low for changes cognitive }(50.0 \%) \text {. }\end{array}$ \\
\hline Mello et al. ${ }^{38}$ & $\begin{array}{l}\text { Cohort } \\
\text { (no control) }\end{array}$ & $\begin{array}{l}12-30 \text { months } \\
\mathrm{N}=83\end{array}$ & $\begin{array}{l}\mathrm{GA}<37 \\
\mathrm{BW}<1500\end{array}$ & $\begin{array}{l}\text { Motor and } \\
\text { cognitive }\end{array}$ & Bayley Scale & $\begin{array}{l}\text { Comparison of means (Chi- } \\
\text { squared, F-test.) }\end{array}$ & $\begin{array}{l}\text { Cerebral ultrasonography (US) was normal in } 68 \\
\text { babies }(81.9 \%) \text { and abnormal in } 15(18.8 \%) \text {. With a } \\
\text { mean age of } 21 \text { months, } 63 \text { children }(75.9 \%) \text { had } \\
\text { normal motor development and } 20(24.0 \%) \text { had } \\
\text { motor abnormalities. The cognitive development } \\
\text { was normal in } 68 \text { children }(81.9 \%) \text {. The negative } \\
\text { predictive value of the cerebral US for motor } \\
\text { development was } 85.3 \% \text {, and for cognitive } \\
\text { development, } 86.8 \% \text {. The positive predictive value } \\
\text { of the cerebral US for motor development was } \\
66.7 \% \text { and for cognitive development, } 42.9 \% \text {. The } \\
\text { probability for children with normal neonatal } \\
\text { ultrasonography to have normal motor and } \\
\text { cognitive development is greater than } 85 \% \text {. }\end{array}$ \\
\hline Mello et al. ${ }^{39}$ & $\begin{array}{l}\text { Cohort } \\
\text { (no control) }\end{array}$ & $N=100$ & $\begin{array}{l}\text { BW: } 1126 \\
\text { GA: } 29.6\end{array}$ & $\begin{array}{l}\text { Motor and } \\
\text { cognitive }\end{array}$ & Bayley Scale & $\begin{array}{l}\text { A multivariate logistic regression } \\
\text { model was constructed. } \\
\text { Neonatal variables and } \\
\text { neuromotor abnormalities up to } \\
6 \text { months of corrected age were } \\
\text { selected } \\
\text { by bivariate analysis. }\end{array}$ & $\begin{array}{l}\text { Mean birth weight was } 1126 \mathrm{~g} \text { (SD: } 240 \text { ). Abnormal } \\
\text { neuromotor development was presented in } 60 \\
\text { children at } 12 \text { months corrected age. }\end{array}$ \\
\hline
\end{tabular}




\begin{tabular}{|c|c|c|c|c|c|c|c|}
\hline Oliveira et al. ${ }^{40}$ & $\begin{array}{l}\text { Case-control } \\
\text { (incl control) }\end{array}$ & $\begin{array}{l}5-6 \text { years } \\
N=46 \\
\mathrm{n}_{1}=23 \leq 1500 \\
9 \text { boys } \\
14 \text { girls } \\
\mathrm{n}_{2}=23 \geq 2500 \\
\text { Sex unknown }\end{array}$ & $\begin{array}{l}\leq 1500 \\
\text { Mean BW: } \\
1201 \pm 177 \\
\text { GA: } 30 \pm 2 \\
\text { Vs. } \\
\geq 2500 \\
\text { BW: } 3273 \pm 348 \\
\text { GA: } 39 \pm 0.4\end{array}$ & $\begin{array}{l}\text { Motor } \\
\text { IQ } \\
\text { Coordination } \\
\text { ADHD symptoms } \\
\text { Environment }\end{array}$ & $\begin{array}{l}\text { M-ABC } \\
\text { WISC } \\
\text { DCDQ } \\
\text { SNAP IV } \\
\text { HOME }\end{array}$ & $\begin{array}{l}\text { Comparison of means } \\
\text { (Mann-Whitney test), Spearman } \\
\text { correlations tests }\end{array}$ & $\begin{array}{l}\text { LBW children were more vulnerable to have motor } \\
\text { and cognitive impairments. Home factors as } \\
\text { significant predictors on motor and cognitive } \\
\text { scores. }\end{array}$ \\
\hline
\end{tabular}

\begin{tabular}{|c|c|c|c|c|c|c|c|}
\hline $\mathrm{Pr}_{41}^{\text {Procianoy et al. }}$ & $\begin{array}{l}\text { Cohort } \\
\text { (incl control) }\end{array}$ & $\begin{array}{l}2 \text { years } \\
\mathrm{N}=96 \\
49 \text { boys } \\
47 \text { girls } \\
\mathrm{n}_{1}=55 \text { SGA } \\
\mathrm{n}_{2}=41 \mathrm{AGE}\end{array}$ & $\begin{array}{l}\text { SGA }<1500 \\
\text { GA: } 31.7 \pm 2 \\
\text { BW: } 1130 \pm 250 \\
\text { vs. } \\
\text { AGE }<1500 \\
\text { GA: } 29.3 \pm 1.6 \\
\text { BW: } 1250 \pm 218\end{array}$ & $\begin{array}{l}\text { Motor and } \\
\text { cognitive }\end{array}$ & Bayley Scale & $\begin{array}{l}\text { Comparison of means (Chi- } \\
\text { squared, F-test.), ANOVA, } \\
\text { ANCOVA }\end{array}$ & $\begin{array}{l}\text { Mental and motor development were similar } \\
\text { between both groups of term infants at } 8,12,18 \text {, and } \\
24 \text { months corrected age. Both groups had similar } \\
\text { neurodevelopment outcome. }\end{array}$ \\
\hline Reis et al. ${ }^{42}$ & $\begin{array}{l}\text { Cohort } \\
\text { (no control) }\end{array}$ & $\begin{array}{l}\mathrm{N}=109 \\
<2 \text { years } \\
(6 \mathrm{~m}, \quad 12 \mathrm{~m}, \quad 18 \\
24 \mathrm{~m})\end{array}$ & $\begin{array}{l}\mathrm{GA}<37 \\
\mathrm{BW}<1500\end{array}$ & $\begin{array}{l}\text { Motor and } \\
\text { cognitive }\end{array}$ & $\begin{array}{l}\text { Bayley-II Scale } \\
\text { MDI }\end{array}$ & $\begin{array}{l}\text { The stability of the scores } \\
\text { between assessments was } \\
\text { verified by the analysis of } \\
\text { variance for repeated measures. } \\
\text { The association of the major } \\
\text { social and neonatal } \\
\text { characteristics with mental } \\
\text { development was confirmed } \\
\text { using multivariate analysis by } \\
\text { linear regression, }\end{array}$ & $\begin{array}{l}\text { The association of the major social and neonatal } \\
\text { characteristics with mental development was } \\
\text { confirmed using multivariate analysis by linear } \\
\text { regression, considering the following outcomes: } \\
\text { mental development indices at } 6 \text { months, } 12 \\
\text { months and between } 18-24 \text { months of corrected } \\
\text { age. The cognitive development index did not show } \\
\text { stability during the first two years, except for } \\
\text { children with neonatal pneumonia }\end{array}$ \\
\hline Schirmer et al. ${ }^{43}$ & $\begin{array}{l}\text { Cross-sectional } \\
\text { (no control) }\end{array}$ & $\begin{array}{l}3 \text { years } \\
N=69 \\
n_{1}=30<1500 \\
n_{2}=391500- \\
2500 \\
\text { Sex unknown }\end{array}$ & $\begin{array}{l}\leq 2500 \\
\text { Subdivision } \\
<1500 \\
\text { vs. } \\
1500-2500 \\
\text { All GA }>37\end{array}$ & $\begin{array}{l}\text { Motor and } \\
\text { cognitive } \\
\text { Motor and } \\
\text { cognitive } \\
\text { Language }\end{array}$ & $\begin{array}{l}\text { Denver-II Test } \\
\text { Bayley-II Scale } \\
\text { Language } \\
\text { Assessment }\end{array}$ & $\begin{array}{l}\text { Chi-squared, } \\
\text { variance (T-test), } \begin{array}{r}\text { Analysis of } \\
\text { multivariate } \\
\text { regression, } \\
\text { (OR, Wald) }\end{array}\end{array}$ & $\begin{array}{l}\text { GA correlates with language development; GA } \\
\text { predicts language acquisition. Gestational age }<32 \\
\text { weeks increases } 3 \text { times the risk for delay in } \\
\text { language acquisition. }\end{array}$ \\
\hline
\end{tabular}




\begin{tabular}{|c|c|c|c|c|c|c|c|}
\hline Silva et al. ${ }^{44}$ & $\begin{array}{l}\text { Cross-sectional } \\
\text { (no control) }\end{array}$ & $\begin{array}{l}4-24 \text { months } \\
\mathrm{N}=69\end{array}$ & $\begin{array}{l}\mathrm{GA}<37 \\
\mathrm{BW}<1500\end{array}$ & $\begin{array}{l}\text { Hand-eye } \\
\text { coordination } \\
\text { Language Posture } \\
\text { Sociability }\end{array}$ & $\begin{array}{l}\text { Brunet Scale } \\
\text { Lèzine's Scale }\end{array}$ & $\begin{array}{l}\text { Data were analyzed using } \\
\text { descriptive and inferential } \\
\text { statistics. }\end{array}$ & $\begin{array}{l}85 \% \text { of scores within the normal range in the third } \\
\text { assessment. The specific areas of hand-eye } \\
\text { coordination and language had the worst initial } \\
\text { results, while posture had the best scores. } \\
\text { Correlation was found between birth weight and } \\
\text { posture, language and social areas at the first } \\
\text { assessment and between birth weight and social } \\
\text { and hand-eye coordination at the third assessment. }\end{array}$ \\
\hline Saccani et al ${ }^{45}$ & $\begin{array}{l}\text { Cross-sectional } \\
\text { (incl control) }\end{array}$ & $\begin{array}{l}0-12 \text { months } \\
\mathrm{N}=42 \\
\mathrm{n} 1=21 \\
\mathrm{n} 2=21\end{array}$ & $\begin{array}{l}<2500 \\
\text { Mean BW: } \\
1886 \pm 402 \\
\text { GA: } 36 \\
\text { Vs } \\
\geq 2500 \\
\text { BW: } 2878 \pm 348 \\
\text { GA: } 36\end{array}$ & Motor & $\begin{array}{l}\text { Alberta Infant } \\
\text { Motor Scale }\end{array}$ & $\begin{array}{l}\text { The independent } t \text {-test, the chi- } \\
\text { square test of Pearson and the } \\
\text { Eta2 test (strong association> } \\
0.60 \text { ). }\end{array}$ & $\begin{array}{l}\text { Fifteen }(71.42 \%) \text { children with low birth weight were } \\
\text { classified as small for gestational age. The mean } \\
\text { motor development score percentile was } \\
17.90 \pm 17.74 \text { for the LBW group and } 34.57 \pm 25.80 \\
\text { for the ABW group, indicating a better motor } \\
\text { development of the second group ( } \mathrm{p}=0.02) \text {. There } \\
\text { was a greater number of children with } \\
\text { developmental delay in the LBW group ( } 52.4 \%) \text {, } \\
\text { whereas in the ABW group most were within the } \\
\text { normal range }(47.6 \%) \text {. }\end{array}$ \\
\hline
\end{tabular}

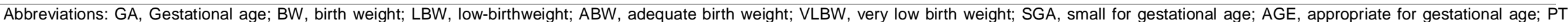

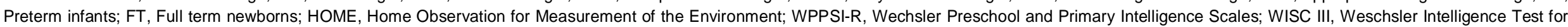

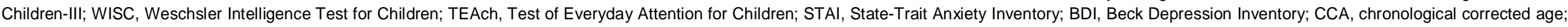

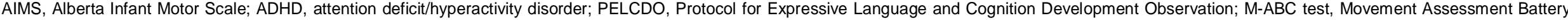

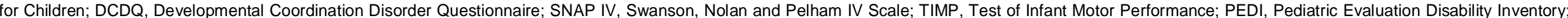

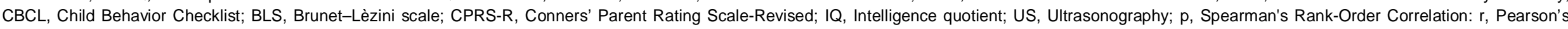

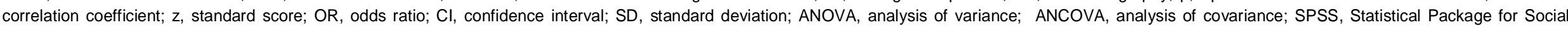
Sciences. 
medRxiv preprint doi: https://doi.org/10.1101/2020.08.31.20178277; this version posted September 2, 2020. The copyright holder for this preprint (which was not certified by peer review) is the author/funder, who has granted medRxiv a license to display the preprint in perpetuity.

All rights reserved. No reuse allowed without permission.

Table 3 Risk of bias assessment adapted from STROBE ${ }^{19}$

\begin{tabular}{|c|c|c|c|}
\hline No. & Author/Year & $\begin{array}{l}\text { Obtained score/ } \\
\text { maximum score }\end{array}$ & $\begin{array}{c}\text { Relative } \\
\text { frequency (\%) }\end{array}$ \\
\hline 01 & Bühler et al. ${ }^{21}$ & $19 / 22^{b}$ & 86 \\
\hline 02 & Carvalho et al. ${ }^{22}$ & $21 / 22^{b}$ & 95 \\
\hline 03 & Eickman et al. ${ }^{23}$ & $21 / 22^{a}$ & 95 \\
\hline 04 & Emond et al. ${ }^{24}$ & $22 / 22^{b}$ & 100 \\
\hline 05 & Espirito Santo et al. ${ }^{2 b}$ & $21 / 22^{a}$ & 95 \\
\hline 06 & Fan et al. ${ }^{26}$ & $20 / 22^{\mathrm{a}}$ & 91 \\
\hline 07 & Fernandes et al. ${ }^{2 \prime}$ & $20 / 22^{\mathrm{a}}$ & 91 \\
\hline 08 & Fuentefria et al. ${ }^{28}$ & $20 / 22^{b}$ & 91 \\
\hline 09 & Grantham-McGregor et & $19 / 22^{b}$ & 86 \\
\hline 10 & Guerra et al. ${ }^{30}$ & $20 / 22^{a}$ & 91 \\
\hline 11 & Guimarães et al. ${ }^{31}$ & $21 / 22^{\mathrm{a}}$ & 95 \\
\hline 12 & Lemos et al. ${ }^{32}$ & $20 / 22^{\mathrm{a}}$ & 91 \\
\hline 13 & Magalhães et al. ${ }^{33}$ & $20 / 22^{\mathrm{a}}$ & 91 \\
\hline 14 & Manacero and Nunes ${ }^{34}$ & $21 / 22^{a}$ & 95 \\
\hline 15 & Meio et al. ${ }^{35}$ & $20 / 22^{b}$ & 91 \\
\hline 16 & Meio et al. ${ }^{36}$ & $20 / 22^{b}$ & 91 \\
\hline 17 & Mello et al. ${ }^{3 \prime}$ & $22 / 22^{b}$ & 100 \\
\hline 18 & Mello et al. ${ }^{3 \triangleleft}$ & $21 / 22^{D}$ & 95 \\
\hline 19 & Mello et al..$^{3 y}$ & $20 / 22^{b}$ & 91 \\
\hline 20 & Oliveira et al. ${ }^{40}$ & $22 / 22^{c}$ & 100 \\
\hline 21 & Procianoy et al..$^{41}$ & $22 / 22^{b}$ & 95 \\
\hline 22 & Reis et al. ${ }^{42}$ & $22 / 22^{D}$ & 100 \\
\hline 23 & Schirmer et al. ${ }^{43}$ & $20 / 22^{\mathrm{a}}$ & 91 \\
\hline 24 & Silva et al. ${ }^{44}$ & $20 / 22^{\mathrm{a}}$ & 91 \\
\hline 25 & Saccani et al. ${ }^{45}$ & $20 / 22^{\mathrm{a}}$ & 91 \\
\hline
\end{tabular}

${ }^{a}$ Cross-sectional prevalence study.

${ }^{\mathrm{b}}$ Cohort study.

${ }^{\mathrm{c}}$ Case-control study. 